\title{
Radiolytic activation of a cytarabine prodrug possessing a 2-oxoalkyl group: one-electron reduction and cytotoxicity characteristics
}

\section{AUTHOR(S):}

Hirata, Nao; Fujisawa, Yusuke; Tanabe, Kazuhito; Harada, Hiroshi; Hiraoka, Masahiro; Nishimoto, Seiichi

\section{CITATION:}

Hirata, Nao ...[et al]. Radiolytic activation of a cytarabine prodrug possessing a 2-oxoalkyl group: one-electron reduction and cytotoxicity characteristics. Organic \& Biomolecular Chemistry 2009, 7(4): 651-654

\section{ISSUE DATE:}

2009-02-21

URL:

http://hdl.handle.net/2433/85293

\section{RIGHT:}

Org. Biomol. Chem., 2009, 7(4), pp.651-654 - Reproduced by permission of The Royal Society of Chemistry (RSC); 許諾条件により本文は2010-02-21に公開; この論文は出版社 版でありません。引用の際には出版社版をご確認ご利用ください。; This is not the published version. Please cite only the published version. 


\section{Radiolytic activation of cytarabine prodrug possessing 2-oxoalkyl group:}

\section{one-electron reduction and cytotoxicity characteristics}

Nao Hirata, ${ }^{\dagger}$ Yusuke Fujisawa, ${ }^{\dagger}$ Kazuhito Tanabe, ${ }^{*,{ }^{\dagger}}$ Hiroshi Harada, ${ }^{\ddagger, \#}$ Masahiro Hiraoka ${ }^{\ddagger}, \#$ and Sei-ichi Nishimoto ${ }^{*}$,

${ }^{\dagger}$ Department of Energy and Hydrocarbon Chemistry, Graduate School of Engineering, Kyoto

University, Katsura Campus, Kyoto 615-8510, Japan

${ }^{\ddagger}$ Department of Radiation Oncology and Image-applied Therapy, Graduate School of Medicine,

Kyoto University, Kyoto 606-8507, Japan

${ }^{\#}$ Nano-medicine Merger Education Unit, Kyoto University, Kyoto 606-8507, Japan 


\section{GRAPHICAL ABSTRACT}

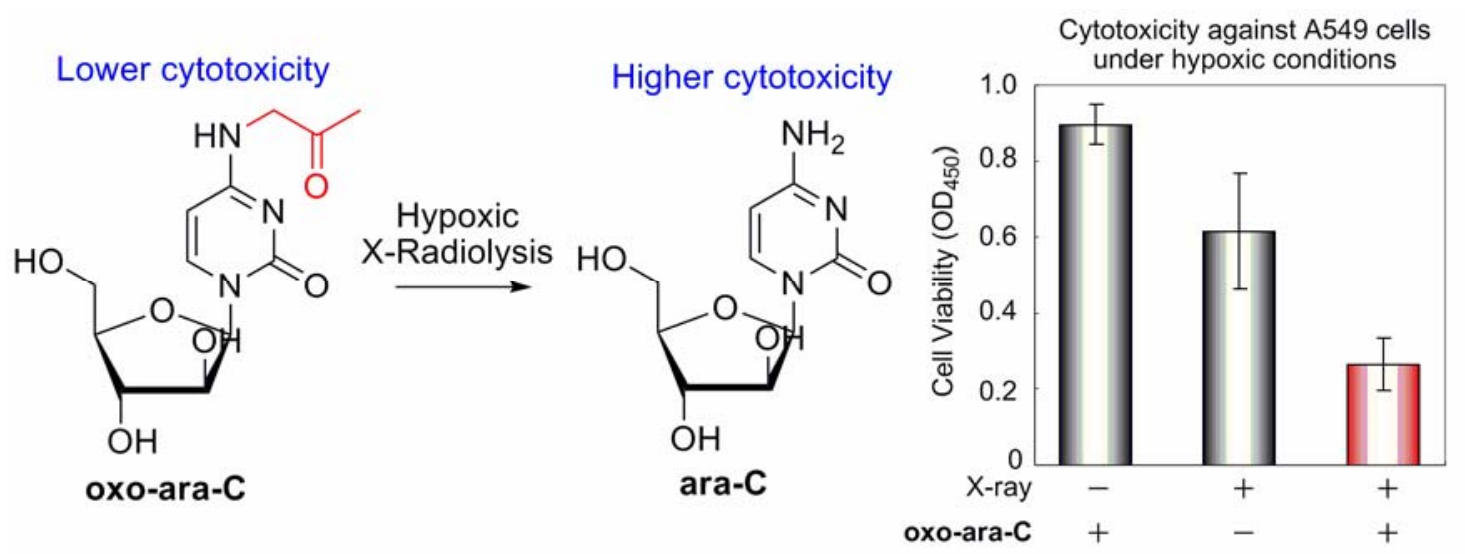

An antitumor agent of cytarabine (ara-C) was conjugated with a 2-oxopropyl group at $\mathrm{N}(4)$ position to obtain a radiation activated prodrug (oxo-ara-C) that releases the toxic parent agent ara-C in hypoxic tumor cells via radiolytic one-electron reduction by hydrated electrons $\left(\mathrm{e}_{\mathrm{aq}}{ }^{-}\right)$. 


\section{Radiolytic activation of cytarabine prodrug possessing 2-oxoalkyl group:}

\section{one-electron reduction and cytotoxicity characteristics}

Nao Hirata, ${ }^{\dagger}$ Yusuke Fujisawa, ${ }^{\dagger}$ Kazuhito Tanabe, ${ }^{*,{ }^{\dagger}}$ Hiroshi Harada, ${ }^{\ddagger, \#}$ Masahiro Hiraoka ${ }^{\ddagger}, \#$ and Sei-ichi Nishimoto ${ }^{*}$,

${ }^{\dagger}$ Department of Energy and Hydrocarbon Chemistry, Graduate School of Engineering, Kyoto

University, Katsura Campus, Kyoto 615-8510, Japan

${ }^{\ddagger}$ Department of Radiation Oncology and Image-applied Therapy, Graduate School of Medicine,

Kyoto University, Kyoto 606-8507, Japan

${ }^{\#}$ Nano-medicine Merger Education Unit, Kyoto University, Kyoto 606-8507, Japan

*corresponding author. Phone: +81-75-383-2500. FAX: +81-75-383-2501,

e-mail: tanabeka@scl.kyoto-u.ac.jp, nishimot@scl.kyoto-u.ac.jp 


\section{Abstract}

An antitumor agent of cytarabine (ara-C) was conjugated with a 2-oxopropyl group at $\mathrm{N}(4)$

position to obtain a radiation activated prodrug (oxo-ara-C) that targets hypoxic tumor tissues to

show a selective cytotoxicity. The parent antitumor agent, ara-C, was confirmed to be released from oxo-ara-C via one-electron reduction upon hypoxic X-irradiation. The prodrug oxo-ara-C was of dramatically reduced cytotoxicity against human lung adenocarcinoma A549 cells relative to ara-C because of the effect of 2-oxopropyl substituent. In contrast, X-irradiation of hypoxic A549 cells containing oxo-ara-C enhanced the cytotoxic effect, indicating that toxic ara-C was preferentially released in hypoxic cells via radiolytic one-electron reduction by hydrated electrons $\left(\mathrm{e}_{\mathrm{aq}}{ }^{-}\right)$. 


\section{Introduction}

Cytarabine (1-beta- $D$-arabinofuranosyl-cytosine; ara-C) synthesized by Walwick and coworkers is a family of antimetabolites. ${ }^{1}$ This deoxycytidine analog undergoes phosphorylation by intrinsic kinases, and is subsequently incorporated into DNA during chain elongation mediated by polymerase, thereby resulting in the inhibition of DNA replication and elongation. ${ }^{2}$ Due to the highly cytotoxic effect, ara-C has been widely used as an antineoplastic and antiviral agent. However, ara-C has drawbacks in clinical applications: typically high dose of ara-C causes serious side effects such as encephalopathy and cerebellar dyfunction. ${ }^{3}$ Therefore, there has been a demand for giving a target specific feature to ara-C that could discriminate between tumor and normal cells for cytotoxicity. In view of a tumor-specific microenvironment of hypoxia as generated from an imbalance between supply and consumption of oxygen in solid tumor tissues, ${ }^{4}$ we have attempted to exploit a new class of antitumor prodrugs that targets a hypoxic microenvironment to show a selective antitumor effect. ${ }^{5}$

We have thus far identified a series of 2-oxoalkyl groups as the effective substituents for 
conjugation to nucleic acid derivatives that is removable by $\mathrm{X}$-irradiation under hypoxic conditions in aqueous solution. ${ }^{6}$ An activation mechanism has been proposed by which the 2-oxoalkyl group undergoes one-electron reduction by hydrated electrons $\left(\mathrm{e}_{\mathrm{aq}}{ }^{-7}\right)^{7}$ generated via radiolysis of water to form the corresponding $\pi^{*}$ anion radical, followed by thermal activation into the $\sigma^{*}$ anion radical and is readily hydrolyzed to release the 2-oxoalkyl group. ${ }^{8}$ We have applied these characteristics of the 2-oxoalkyl group to develop prodrugs of antitumor agents, 1-(2'-oxopropyl)-5-fluorouracil and 2'-deoxy-5-fluoro-3-(2'-oxoalkyl)uridine, which are activated to release 5-fluorouracil (5-FU) or 5-fluoro-2'-deoxyuridine (5-FdUrd), respectively, upon hypoxic X-irradiation. ${ }^{6}$

In this study, we designed an ara-C derivative possessing a 2-oxopropyl group at $\mathrm{N}(4)$ position (oxo-ara-C) to obtain a novel radiation-activated prodrug. We performed the radiolytic one-electron reduction of oxo-ara-C and evaluated its cytotoxic effect under hypoxic conditions. The 2-oxopropyl group was readily removed from oxo-ara-C upon hypoxic X-irradiation. Analysis of cell viability with SF assay revealed that oxo-ara-C released the toxic parent ara-C via one-electron reduction as induced upon X-irradiation under hypoxic conditions, thereby resulting in 
cytotoxic effects.

\section{Results and discussion}

The synthesis of oxo-ara-C is outlined in Scheme 1 . Triazole group of $\mathbf{1}^{9}$ was substituted with 1-amino-2,2-dimethoxypropane ${ }^{10}$ to give an acetal derivative 2 . Hydrolysis of 2 furnished the desired oxo-ara-C. A control compound 3 without a carbonyl group at the $\mathrm{N}(4)$ position was prepared by the coupling of $\mathbf{1}$ with propylamine.

We examined the efficiency of radiolytic one-electron reduction of oxo-ara-C for controlled releasing of ara-C in an argon-purged aqueous solution containing 2-methyl-2-propanol (10 mM) as the scavenger of oxidizing hydroxyl radicals $\left({ }^{\circ} \mathrm{OH}\right){ }^{7,11}$ Under these radiolysis conditions, reducing hydrated electrons $\left(\mathrm{e}_{\mathrm{aq}}{ }^{-}\right)$were generated as the major active species. Fig. 1 shows a representative reaction profile analyzed by HPLC of the radiolytic one-electron reduction of oxo-ara-C by the resulting $\mathrm{e}_{\mathrm{aq}}{ }^{-}$under hypoxic conditions. The appearance of a single new peak in

Fig. 1 was attributable to the formation of the parent ara-C, as confirmed by the overlap injection 
of authentic samples in the HPLC analysis. The $G$ values ${ }^{12}$ were $151 \mathrm{nmol} \mathrm{J}^{-1}$ for the decomposition of oxo-ara-C and $69 \mathrm{nmol} \mathrm{J^{-1 }}$ for the formation of corresponding ara-C, respectively. Thus, 46\% of the decomposed oxo-ara-C was converted to ara- $\mathbf{C}$ upon hypoxic $\mathrm{X}$-irradiation. In contrast, the radiolytic decomposition of oxo-ara-C was dramatically suppressed under aerobic conditions; the

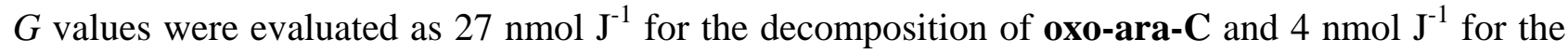
formation of the corresponding ara-C, respectively. These results indicate that oxo-ara-C is activated to release ara-C in a hypoxia selective manner, as were observed in the cases of the 5-FU and 5-FdUrd prodrugs possessing 2-oxoalkyl groups. ${ }^{6,11}$

To confirm the mechanistic validity of one-electron reduction of oxo-ara-C by $\mathrm{e}_{\mathrm{aq}}^{-}$, we conducted a control X-irradiation of oxo-ara-C in an aqueous solution purged with nitrous oxide $\left(\mathrm{N}_{2} \mathrm{O}\right)^{13}$ gas, which efficiently captures reducing species of $\mathrm{e}_{\mathrm{aq}}{ }^{-}$to produce oxidizing species of ${ }^{\bullet} \mathrm{OH}$. As shown in Table 1, the formation of ara-C was suppressed to greater extent in the presence of $\mathrm{N}_{2} \mathrm{O}$ relative to the argon-purged aqueous solution, while efficient decomposition of oxo-ara-C occurred due to the ${ }^{\bullet} \mathrm{OH}$ reaction (see also Fig. S1, S2.). Thus, it is reasonable to conclude that 
reducing $\mathrm{e}_{\mathrm{aq}}{ }^{-}$is essential for the activation of oxo-ara-C and the concomitant release of ara-C.

In a separate experiment, we carried out radiolytic reduction of $\mathrm{N}(4)$-substituted ara-C without a carbonyl group 3 in aqueous solution. As shown in Table 1, hypoxic irradiation of $\mathbf{3}$ failed to release ara-C, indicating that the carbonyl moiety is a key structural unit for the release of ara-C via one-electron reduction of oxo-ara-C by $\mathrm{e}_{\mathrm{aq}}^{-}$.

Understanding of the function of oxo-ara-C in living cells is important for its biological applications. We therefore assessed the cytotoxicity of ara-C and oxo-ara-C toward A549 cells (human lung adenocarcinoma). A549 cells were cultured with various concentrations of ara-C or oxo-ara-C under aerobic conditions for 72 h, and subjected to a cell viability assay (Fig. 2). The IC $_{50}$ values were 20.7 and $0.38 \mu \mathrm{M}$ for oxo-ara-C and ara-C, respectively, indicating that a small modification of ara-C by a substituent such as the 2-oxopropyl group can effectively reduce the cytotoxicity of the parent antitumor agent. This result may be promising for further investigations to identify whether the dose of oxo-ara-C could be more increased without considerable side effects, compared to ara-C. 
We subsequently exposed A549 cells to varying doses of X-ray in the presence or absence of

oxo-ara-C under aerobic or hypoxic conditions, and characterized the hypoxia- and radiation-dependent cytotoxic effects of oxo-ara-C (Fig. 3). In accord with the suppression of cytotoxic effects as described above, the cells were viable even in the presence of $3.3 \mu \mathrm{M}$ oxo-ara-C without X-irradiation (compare entries 1 to 2). ${ }^{14}$ Although the A549 cells were practically resistant to radiation under hypoxic conditions (entry 7), oxo-ara-C showed a striking property to significantly enhance the radiation sensitivity of A549 cells (entry 8). In contrast, oxo-ara-C had little effect on the radiation sensitibity under aerobic conditions (compare entries 5 to 6). These results strongly suggest that oxo-ara-C preferentially released toxic ara-C via radiolytic one-electron reduction in hypoxic cells and thereby resulted in enhanced cytotoxicity, consistent with the radiation chemical reactivity.

Thus, oxo-ara-C has been demonstrated to be useful as a radiation-activated prodrug that targets hypoxic tumor cells to show a cytotoxic effect. Incorporation of a 2-oxoalkyl group into ara-C dramatically reduced its cytotoxicity, while the toxic activity was recovered upon hypoxic 
irradiation. Although the suppression mechanism of intrinsic cytotoxicity of oxo-ara-C in the presence of 2-oxoalkyl group remains unclear, it is presumable that the steric hindrance and/or disturbance of hydrogen bonding at N(4) position may inhibit the recognition of intracellular DNA polymerases, which are key enzymes involving in appearance of the cytotoxic effects of ara-C. In order to confirm this hypothesis, further mechanistic studies using DNA polymerase and triphosphate of oxo-ara-C are in progress.

\section{Conclusion}

In summary, we designed and synthesized an ara-C derivative possessing a 2-oxopropyl group at $\mathrm{N}(4)$ position (oxo-ara-C) as a radiation-activated prodrug. Oxo-ara-C was activated to release ara-C by $\mathrm{e}_{\mathrm{aq}}{ }^{-}$as generated in radiolysis of water under hypoxic conditions. Assessment of the viability of A549 cells revealed that incorporation of 2-oxoalkyl group into ara-C resulted in a dramatic suppression of the cytotoxic effect, while hypoxic X-irradiation recovered the cytotoxicity via removal of the 2-oxoalkyl group to re-generate active ara-C. Thus, the ara-C derivatives 
possessing 2-oxoalkyl groups are promising candidates as a new class of radiation-activated prodrugs for the treatment of hypoxic tumor tissues. 


\section{Experimantal}

\section{General}

All reactions were carried out under a dry nitrogen atmosphere using freshly distilled solvents

unless otherwise noted. Reagents were purchased from Aldrich, Wako pure chemical industries and

Nacalai tesque, and used as received. Ultrapure water was obtained from YAMATO WR-600A.

Precoated TLC (Merck silica gel $60 \mathrm{~F}_{254}$ ) plates were used for monitoring the reactions. Column chromatography was carried out on Wakogel C-300 (Wako pure chemical industries). ${ }^{1} \mathrm{H}$ NMR spectra were measured with JOEL JMN-AL-300 (300 MHz) or JOEL JMN-AL-400 (400 MHz)

spectrophotometers at ambient temperature. ${ }^{13} \mathrm{C}$ NMR spectra were measured with JOEL JMN-AL-300 (75.5 MHz) or JOEL JMN-AL-400 (100 MHz) spectrophotometers at ambient temperature. Coupling constants ( $J$ values) are reported in Hertz. The chemical shifts are expressed in ppm downfield from tetramethylsilane, using residual methanol ( $\delta=3.30$ in ${ }^{1} \mathrm{H}$ NMR, $\delta=49.0$ in ${ }^{13} \mathrm{C}$ NMR) as an internal standard. Multiplicity is designed as singlet (s), doublet (d), triplet (t), doublet-doublet (dd), or multiplet (m). FAB Mass spectra were recorded on JOEL JMS-SX102A 
spectrometer, using glycerol matrix. A Rigaku RADIOFLEX-350 was used for X-irradiation.

High-performance liquid chromatography (HPLC) was performed with Shimadzu LC-6A system.

Sample solutions were injected on a reversed phase column (Inertsil ODS-3, GL Science Inc., $\phi 4.6$

$\times 150 \mathrm{~nm})$. The $0.1 \mathrm{M}$ triethylamine $\left(\mathrm{Et}_{3} \mathrm{~N}\right) 5 \mathrm{vol} \%$ acetonitrile/water solution containing acetic acid, pH 7.0 was delivered as mobile phase at a flow rate of $0.6 \mathrm{ml} / \mathrm{min}$ at $40{ }^{\circ} \mathrm{C}$. The elution peaks were monitored at $260 \mathrm{~nm}$ wavelength.

\section{4-(2,2-Dimethyoxypropylamino)-1-( $\beta$-D-arabinofuranosyl)pyrimidine-2-(1H)-one (2)}

1-Amino-2,2-dimethoxypropane ${ }^{10}$ (796 $\mathrm{mg} 6.68 \mathrm{mmol}$ ) was added to a solution of $\mathbf{1}^{9}$ (4-(1,2,4-Triazol-yl)-1-( $\beta$-D-2,3,5-tri-O-acetylarabinofuranosyl)pyrimidine-2(1H)-one, $167 \mathrm{mg}$, $0.40 \mathrm{mmol})$ in dioxane $(1.2 \mathrm{ml})$ and stirred for $9.5 \mathrm{~h}$ at $80{ }^{\circ} \mathrm{C}$. The solvent was removed under reduced pressure. The crude product was purified by column chromatography $\left(\mathrm{SiO}_{2} 6 \%\right.$ methanol-chloroform) to give 2 (71 mg, 52\%) as a white solid; mp $171-173{ }^{\circ} \mathrm{C} ;{ }^{1} \mathrm{H}$ NMR $\left(\mathrm{CD}_{3} \mathrm{OD}\right.$, $400 \mathrm{MHz}) \delta 7.75$ (d, 1H, $J=7.6 \mathrm{~Hz}), 6.16$ (d, 1H, $J=4.0 \mathrm{~Hz}), 5.93$ (d, 1H, $J=7.6 \mathrm{~Hz}), 4.16$ (dd, $1 \mathrm{H}, J=2.4,3.6 \mathrm{~Hz}$ ), 4.04 (dd, 1H, $J=2.4,2.4 \mathrm{~Hz}$ ), 3.92 (m, 1H), 3.79 (m, 2H), 3.58 (s, 2H), 3.23 (s, 
6H), 1.28 (s, 3H); ${ }^{13} \mathrm{C}$ NMR (CD $\left.3 \mathrm{OD}, 75.5 \mathrm{MHz}\right) \delta 165.9,158.7,143.0,101.8,95.7,88.3,86.4$,

78.2, 76.8, 62.8, 48.8, 48.8, 45.3, 20.5; FABMS (glycerol) $\mathrm{m} / \mathrm{z} 346\left[(\mathrm{M}+\mathrm{H})^{+}\right]$; HRMS calcd. for

$\mathrm{C}_{14} \mathrm{H}_{24} \mathrm{~N}_{3} \mathrm{O}_{7}\left[(\mathrm{M}+\mathrm{H})^{+}\right]$346.1614, found 346.1611.

4-propylamino-1-( $\beta$-D-arabinofuranosyl)pyrimidine-2-(1H)-one (3)

Propylamine $(0.23 \mathrm{ml}, 2.80 \mathrm{mmol})$ was added to a solution of $\mathbf{1}^{9}$

(4-(1,2,4-Triazol-yl)-1-( $\beta$-D-2,3,5-tri-O-acetylarabinofuranosyl)pyrimidine-2(1H)-one, $43.5 \mathrm{mg}$,

$0.103 \mathrm{mmol})$ in ethanol $(0.3 \mathrm{ml})$ at room temperature. After $4.5 \mathrm{~h}$ the product was concentrated

under reduced pressure. The crude product was purified by column chromatography $\left(\mathrm{SiO}_{2} 1 \% \mathrm{Et}_{3} \mathrm{~N}\right.$,

9\% methanol-chloroform) to give 3 (21 mg, 71\%) as a white solid; mp 194-195 ${ }^{\circ} \mathrm{C} ;{ }^{1} \mathrm{H}$ NMR

$\left(\mathrm{CD}_{3} \mathrm{OD}, 300 \mathrm{MHz}\right) \delta 7.72(\mathrm{~d}, 1 \mathrm{H}, J=7.5 \mathrm{~Hz}), 6.17(\mathrm{~d}, 1 \mathrm{H}, J=3.9 \mathrm{~Hz}), 5.79(\mathrm{~d}, 1 \mathrm{H}, J=7.8 \mathrm{~Hz})$,

$4.16(\mathrm{~m}, 1 \mathrm{H}), 4.07$ (m, 1H), $3.93(\mathrm{~m}, 1 \mathrm{H}), 3.80(\mathrm{~m}, 2 \mathrm{H}), 3.32(\mathrm{~m}, 2 \mathrm{H}), 1.60(\mathrm{~m}, 2 \mathrm{H}, J=7.2 \mathrm{~Hz})$,

0.96 (t, 3H, $J=7.2 \mathrm{~Hz}) ;{ }^{13} \mathrm{C}$ NMR $\left(\mathrm{CD}_{3} \mathrm{OD}, 100 \mathrm{MHz}\right) \delta 165.4,158.6,142.5,95.6,88.2,86.3,78.2$,

76.8, 62.8, 43.4, 23.3, 11.7; FABMS (glycerol) $\mathrm{m} / \mathrm{z} 286\left[(\mathrm{M}+\mathrm{H})^{+}\right]$; HRMS calcd. for $\mathrm{C}_{12} \mathrm{H}_{20} \mathrm{~N}_{3} \mathrm{O}_{5}$

$\left[(\mathrm{M}+\mathrm{H})^{+}\right]$286.1403, found 286.1394. 


\section{4-(2-oxopropylamino)-1-( $\beta$-D-arabinofuranosyl)pyrimidine-2-(1H)-one (4) (oxo-ara-C)}

2 (20 mg $0.058 \mathrm{mmol}$ ) was hydrolyzed by treatment with aqueous $1 \mathrm{M}$ oxalic acid in THF

$(0.3 \mathrm{ml})$ at room temperature for $5 \mathrm{~h}$. The solvent was evaporated under reduced pressure and the crude product was purified by column chromatography $\left(\mathrm{SiO}_{2} 1 \% \mathrm{Et}_{3} \mathrm{~N}, 12 \%\right.$ methanol-chloroform)

to give oxo-ara-C (7.7 mg, 44\%) as a white solid; mp $180-182{ }^{\circ} \mathrm{C} ;{ }^{1} \mathrm{H}$ NMR $\left(\mathrm{CD}_{3} \mathrm{OD}, 300 \mathrm{MHz}\right)$

$\delta 7.79(\mathrm{~d}, 1 \mathrm{H}, J=7.5 \mathrm{~Hz}), 6.15(\mathrm{~d}, 1 \mathrm{H}, J=3.8 \mathrm{~Hz}), 5.93$ (d, 1H, $J=7.5 \mathrm{~Hz}), 4.26$ (s, 2H), 4.16 (dd, 1H, $J=2.4,3.6 \mathrm{~Hz}$ ), 4.04 (dd, $1 \mathrm{H}, J=2.8,2.6 \mathrm{~Hz}), 3.92(\mathrm{~m}, 1 \mathrm{H}), 3.79(\mathrm{~m}, 2 \mathrm{H}), 2.18(\mathrm{~s}, 3 \mathrm{H}) ;{ }^{13} \mathrm{C}$ NMR (CD 3 OD, 75.5 MHz) $\delta$ 206.0, 165.6, 158.5, 143.4, 95.4, 88.4, 86.6, 78.2, 76.8, 62.8, 51.3,

27.1; FABMS (glycerol) $\mathrm{m} / z 300\left[(\mathrm{M}+\mathrm{H})^{+}\right]$; HRMS calcd. for $\mathrm{C}_{12} \mathrm{H}_{18} \mathrm{~N}_{3} \mathrm{O}_{6}\left[(\mathrm{M}+\mathrm{H})^{+}\right] 300.1196$, found 300.1189 .

\section{Radiolytic reduction}

Aqueous solutions of oxo-ara-C and $3(100 \mu \mathrm{M})$, containing 2-methyl-2-propanol (10 mM),

were purged with argon or nitrous oxide for $15 \mathrm{~min}$ and then irradiated in a sealed glass ampoule at

ambient temperature with an X-ray source (4.0 Gy $\left.\mathrm{min}^{-1}\right)$. After the X-irradiation, the solution was 
immediately subjected to HPLC analysis.

\section{Assessment of cytotoxicity toward A549 cells}

A549 cells were cultured in Dulbecco's modified Eagle’s minimum essential medium

(DMEM) containing 10\% fetal bovine serum (FBS). The cells were seeded into 96-well plates

(2000 cells/well) and cultured at $37{ }^{\circ} \mathrm{C}$ in a well-humidified incubator with $5 \% \mathrm{CO}_{2}$ and $95 \%$ air

(aerobic condition) for 24 hours. The cells were then incubated with the various concentrations of

ara-C or oxo-ara-C under aerobic conditions for 72 hours, and added with $11 \mu \mathrm{L}$ of Cell Count

Reagent $\mathrm{SF}^{15}$ (nacalai, Japan). The plates were further incubated at $37^{\circ} \mathrm{C}$ for 2 hours and the cell viability assay was performed using Microplate Reader (BIO-RAD).

\section{Radiation-induced cytotoxicity of oxo-ara-C}

A549 cells were seeded into 96-well plates (2000 cells/well) and incubated at $37{ }^{\circ} \mathrm{C}$ for 24

hours under aerobic or hypoxic conditions. For the hypoxic treatment $(<0.02 \%$ of oxygen), the cells were treated in a hypoxic chamber, BACTRON- II (Sheldon Manufacturing Inc., Cornelius,

OR, USA). The plates kept under aerobic or hypoxic conditions using Anaeron Pack System 
(Mitsubishi Gas Chemical Company Inc., Japan) were X-irradiated at a dose of 4 Gy and incubated

for 72 hours under aerobic conditions. After adding $12 \mu \mathrm{L}$ of Cell Count Reagent SF solution

(nacalai, Japan) to each well, and the cell viability assay was performed as described above. 


\section{References}

1 (a) J. S. Evans, E. A. Musser, L. Bostwick and G. D. Mengel, Cancer Res., 1964, 24, 1285-1293;

(b) K. Ooi, Yakugaku Zasshi, 2002, 122, 471-480.

2 (a) J. J. Furth and S. S. Cohen, Cancer Res., 1968, 28, 2061-2067; (b) P. P. Major, E. M. Egan, D.

J. Herrick and D. W. Kufe, Biochem. Pharmacol., 1982, 31, 2937-2940; (c) D. Kufe, D. Spriggs, E.

M. Egan and D. Munroe, Blood, 1984, 64, 54-58.

3 D. R. Macdonald, Neurol. Clin., 1991, 9, 955-967.

4 (a) A. L. Harris, Nat. Rev. Cancer, 2002, 2, 38-47; (b) S. Kizaka-Kondo, M. Inoue, H. Harada and

M. Hiraoka, Cancer Sci., 2003, 94, 1021-1028.

5 K. Tanabe, Z. Zhang, T. Ito, H. Hatta and S. Nishimoto, Org. Biomol. Chem., 2007, 5, 3745-3757.

6 (a) K. Tanabe, H. Kanezaki, H. Ishii and S. Nishimoto, Org. Biomol. Chem., 2007, 5, 1242-1246.

(b) Y. Shibamoto, L. Zhou, H. Hatta, M. Mori and S. Nishimoto, Int. J. Radiat. Oncol. Biol. Phys.,

2001, 49, 407-413; (c) Y. Shibamoto, Y. Tachi, K. Tanabe, H. Hatta and S. Nishimoto, Int. J. Radiat. 
Oncol. Biol. Phys., 2004, 58, 397-402; (d) K. Tanabe, Y. Mimasu, A. Eto, Y. Tachi, S. Sakakibara,

M. Mori, H. Hatta and S. Nishimoto, Bioorg. Med. Chem., 2003, 11, 4551-4556

7 Radiolysis of diluted aqueous solution at around $\mathrm{pH} 7.0$ produces primary water radicals such as oxidizing hydroxyl radicals $\left({ }^{\circ} \mathrm{OH}\right)$, reducing hydrated electrons $\left(\mathrm{e}_{\mathrm{aq}}{ }^{-}\right)$and reducing hydrogen atoms $\left({ }^{\circ} \mathrm{H}\right)$ with the $G$ values of $G\left({ }^{\bullet} \mathrm{OH}\right)=280 \mathrm{nmol} \mathrm{J}{ }^{-1}, G\left(\mathrm{e}_{\mathrm{aq}}{ }^{-}\right)=280 \mathrm{nmol} \mathrm{J}{ }^{-1}$, and $G\left({ }^{\bullet} \mathrm{H}\right)=60 \mathrm{nmol} \mathrm{J}{ }^{-1}$, respectively.

8 M. Mori, T. Ito, S. Teshima, H. Hatta, S. Fujita and S. Nishimoto, J. Phys. Chem., 2006, 110, $12198-12204$.

9 K. J. Divakar and C. B. Reese, J. Chem. Soc. Perkin Trans., 1982, 5, 1171-1176.

10 R. Calabretta, C. Giordano, C. Gallina, V. Morea, V. Consalvi and R. Scandurra, Eur. J. Med.

Chem., 1995, 30, 931-941.

11 M. Mori, H. Hatta and S. Nishimoto, J. Org. Chem., 2000, 65, 4641-4647.

12 The number of molecules produced or changed per $1 \mathrm{~J}$ of radiation energy absorbed by the reaction system. 
13 Dissolved $\mathrm{N}_{2} \mathrm{O}$ exclusively scavenges reducing hydrated electrons to produce hydroxyl radicals,

as follows: $\mathrm{e}_{\mathrm{aq}}{ }^{-}+\mathrm{N}_{2} \mathrm{O} \rightarrow{ }^{\bullet} \mathrm{OH}+\mathrm{OH}^{-}+\mathrm{N}_{2} \quad\left(\mathrm{k}=9.1 \times 10^{9} \mathrm{dm}^{3} \mathrm{~mol}^{-1} \mathrm{~s}^{-1}\right)$

14 Without X-irradiation, the effect of oxygen on the cell viability is negligible independent of the presence or the absence of oxo-ara-C (Fig. 3, entry 1-4).

15 M. Ishiyama, Y. Miyazono, K. Sasamoto, Y. Ohkura and K. Ueno, Talanta, 1997, 44, 1299-1305. 


\section{FIGURES}

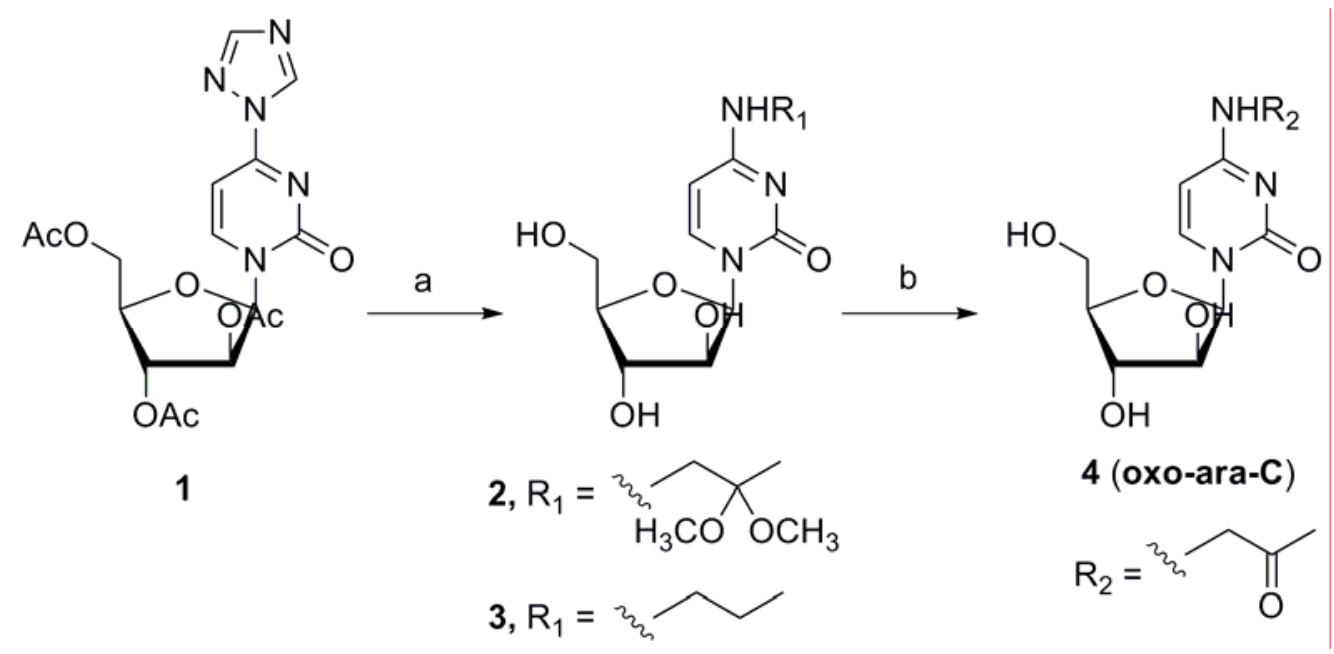

Scheme 1. Reagents and conditions: (a) 1-amino-2,2-dimethoxypropane, dioxane, $80{ }^{\circ} \mathrm{C}, 9.5 \mathrm{~h}$ (for

2, 52\%); propylamine, ethanol, room temperature, 4.5 h (for 3, 71\%); (b) 2, oxalic acid, THF, room temperature, 5 h, (44\%) 


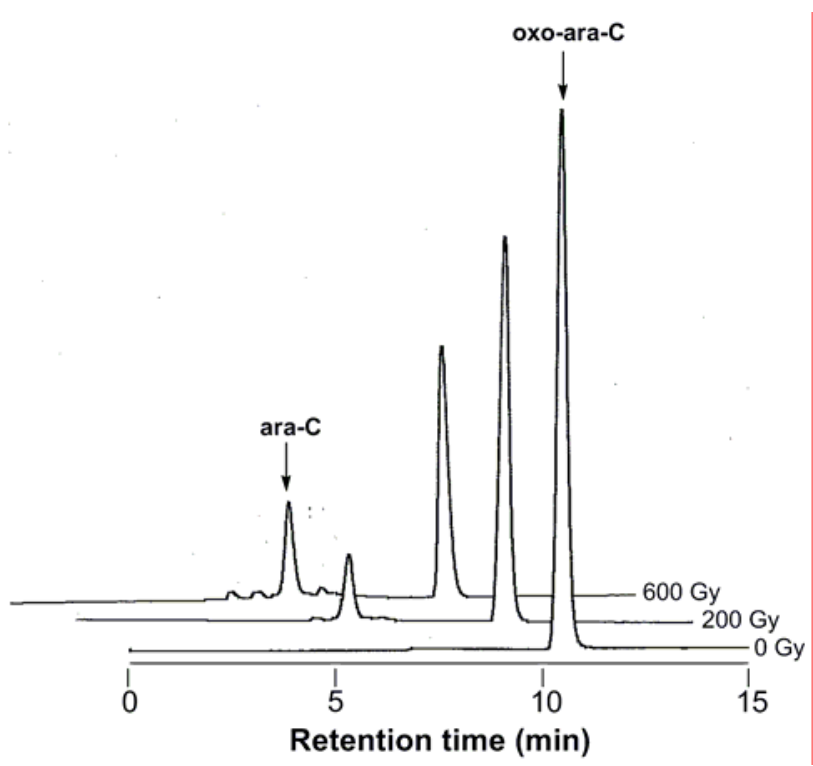

Fig. 1 HPLC profiles for the one-electron reduction of oxo-ara-C $(100 \mu \mathrm{M})$ in the hypoxic

X-radiolysis (0, 200, and $600 \mathrm{~Gy})$ of aqueous solution containing 2-methyl-2-propanol (10 mM). 
Table 1. $G$ values for the decomposition of oxo-ara-C and for the formation of ara-C in the

X-radiolysis in several gas-saturated solutions.

\begin{tabular}{llll}
\hline & & \multicolumn{2}{c}{$G$ value / nmol J } \\
\cline { 3 - 4 } Compound & (saturating gas) & Decomposition & Formation \\
\hline oxo-ara-C & (argon) & 151 & 69 \\
oxo-ara-C & (air) & 27 & 4 \\
oxo-ara-C & (nitrous oxide) & 141 & 5 \\
3 & (argon) & 130 & $\mathrm{ND}^{\mathrm{a}}$ \\
\hline
\end{tabular}

${ }^{\text {a }}$ Not detected 


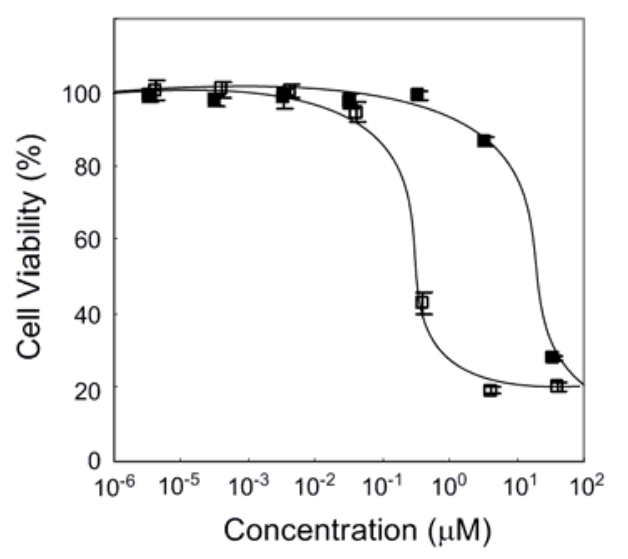

Fig. 2 Cytotoxicity of ara-C and oxo-ara-C against A549 tumor cells. A549 cells were incubated with indicated concentrations of ara-C or oxo-ara-C under aerobic conditions for 72 hours. To calculate the cell viability in each conditions, SF counts $\left(\mathrm{OD}_{450}\right)$ in each drug concentration were compared to those in minimal drug concentrations. ara-C: open square, oxo-ara-C: closed square.

Results are shown with the mean \pm S.D. $\mathrm{n}=3$. 


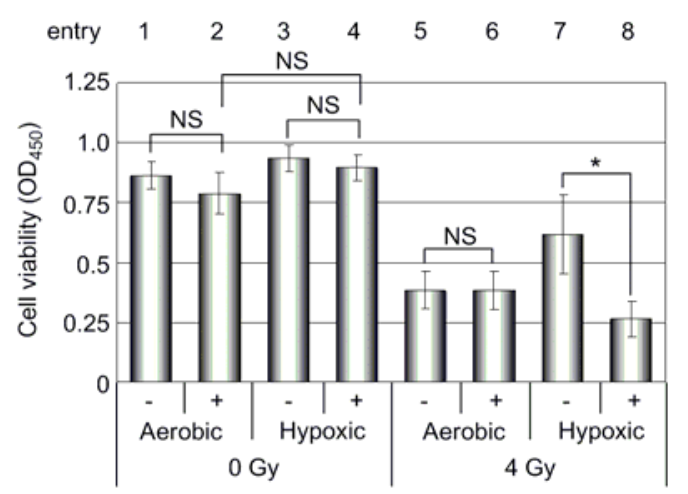

Fig. 3 Radiation-induced cytotoxicity of oxo-ara-C against A549 cells under hypoxic conditions.

A549 cells were cultured in the presence (+) or absence (-) of $3.3 \mu \mathrm{M}$ oxo-ara-C, and X-irradiated

(4 Gy) under aerobic or hypoxic conditions. Results are shown with the mean \pm S.D. $\mathrm{n}=3$ (* $\mathrm{P}<$ 0.05. NS: not significant). 


\section{Electronic Supplementary Information}

\section{Radiolytic activation of cytarabine prodrug possessing 2-oxoalkyl group:}

\section{one-electron reduction and cytotoxicity characteristics}

Nao Hirata, ${ }^{\dagger}$ Yusuke Fujisawa, ${ }^{\dagger}$ Kazuhito Tanabe, ${ }^{*,{ }^{\dagger}}$ Hiroshi Harada, ${ }^{\ddagger, \#}$ Masahiro Hiraoka ${ }^{\ddagger}, \#$

and Sei-ichi Nishimoto ${ }^{*}{ }^{\dagger}$

${ }^{\dagger}$ Department of Energy and Hydrocarbon Chemistry, Graduate School of Engineering, Kyoto

University, Katsura Campus, Kyoto 615-8510, Japan

${ }^{\ddagger}$ Department of Radiation Oncology and Image-applied Therapy, Graduate School of Medicine,

Kyoto University, Kyoto 606-8507, Japan

${ }^{\#}$ Nano-medicine Merger Education Unit, Kyoto University, Kyoto 606-8507, Japan

*corresponding author. Phone: +81-75-383-2500. FAX: +81-75-383-2501,

e-mail: tanabeka@scl.kyoto-u.ac.jp, nishimot@scl.kyoto-u.ac.jp 
(a)

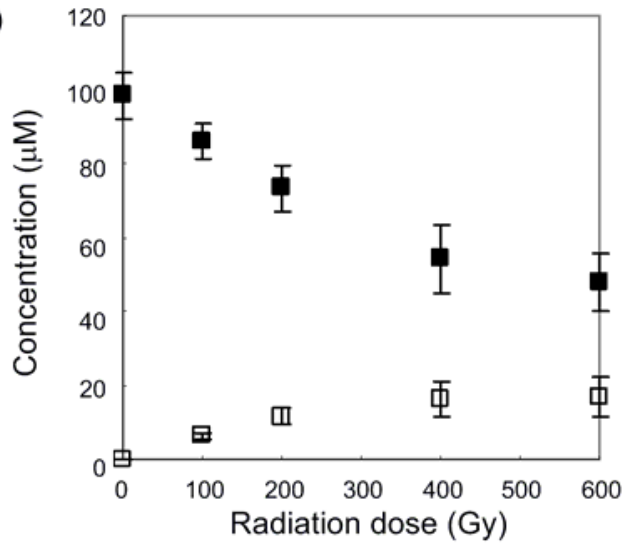

(b)

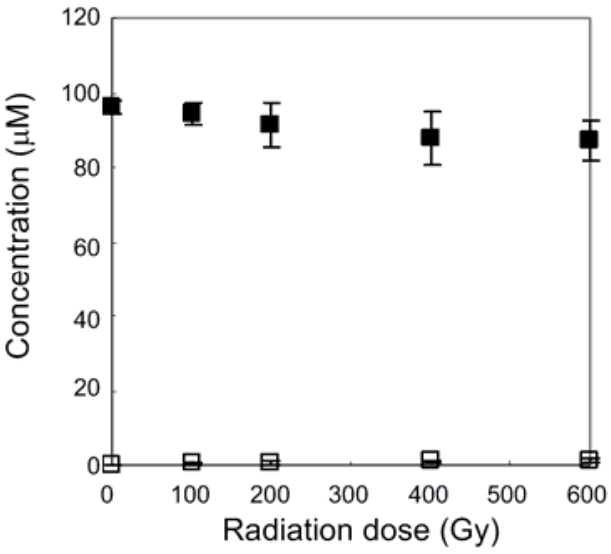

(c)

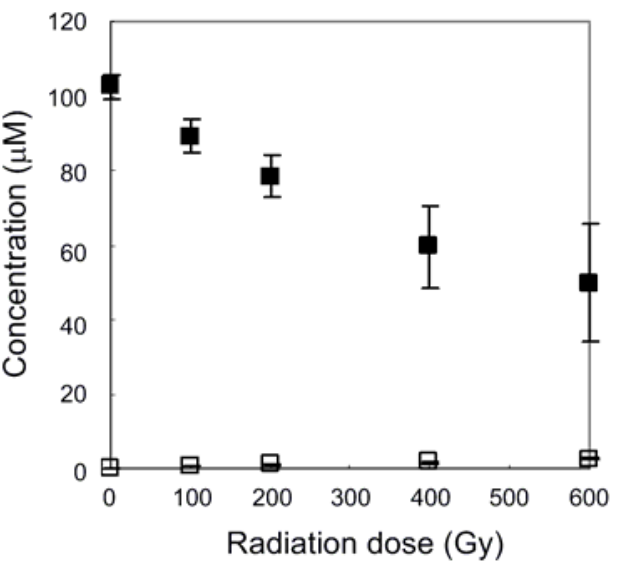

Fig. S1. Radiolytic reduction of $100 \mu \mathrm{M}$ oxo-ara-C (closed square) to release ara-C (open square)

in hypoxic (a), aerobic (b) and $\mathrm{N}_{2} \mathrm{O}$-saturated (c) aqueous solutions containing 2-metyl-2-propanol $(10 \mathrm{mM})$ 

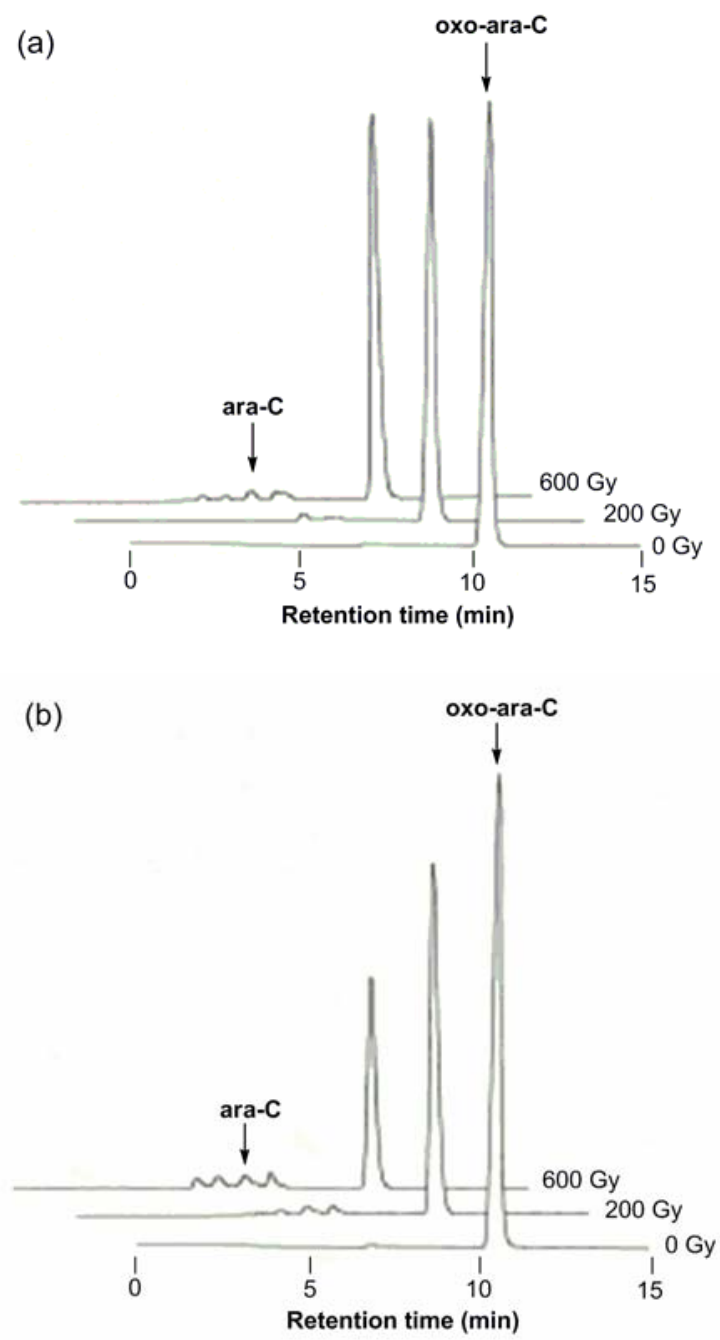

Fig. S2. HPLC profiles for the X-radiolysis (0, 200, and $600 \mathrm{~Gy})$ of oxo-ara-C (100 $\mu \mathrm{M})$ in aerobic (a) and $\mathrm{N}_{2} \mathrm{O}$-saturated (b) aqueous solutions containing 2-methyl-2-propanol (10 mM) 